\title{
Multiculturalism in Schools: A Case Study at MAN Insan Cendekia Gorontalo
}

\author{
Hanisah Hanafi \\ Universitas Negeri Gorontalo \\ Hanisahhanafi65@gmail.com
}

\begin{abstract}
This paper aims at examining patterns of student management and interaction. The study employed amixedapproachto describe student interaction as well as touncover, understand, anddescribethe student management and interaction patterns depicted in the sociometry at MAN Insan Cendekia. The results show that 1) the management and student patterns have begun to be appliedwhen the students are accepted as new students until the end of the study, ranging from student orientation, academic activities in the classroom, setting of dormitories, religious, and student activities. The pattern of management focuses on the academiclevel, and ethnic diversity, which is arranged for all groups, whose members vary, and in many kinds of activities, i.e., different academic levels and different ethnicity. All elements in madrasah's social structure play a role in the formation of the meaning of togetherness among students. A social process which is a development cycle that show the social structure, prejudice, discrimination can bee liminated and the conflict of values can be maintained; 2 )the bases that unite the students are the age and similar formal status of students. Symbols are created through the provision of meaning or value to the management ofmadrasah that creates the patterns of interaction among students. Interaction patterns formed by the management is applied, i.e.,a pattern thatindicatesthe passage ofthe ideology ofmulticulturalism.
\end{abstract}

Keywords. multicultural, interaction pattern, diversity, multi-ethnicity

\section{INTRODUCTION}

The structure of Indonesian community has two unique characteristics, i.e. horizontal structure, in which the Indonesian community is symbolizedwith the reality of the social entity existence based on differences of ethnics, religions, customs, and regions. Meanwhile, vertically, the structure of community inIndonesia is symbolized by sharp vertical differences between the upper layer and the lower layer of the community.

From this diversity, the multicultural community arises through the awareness that people who live ina community are plural. The diversity is not only potential to understand and respect each other but also has potential to give rise to a conflict. Each culture and community has their own way of living which is understood by the community and the context of that culture and community [1]. Therefore, a multicultural community is a concept that refers to a perspective of diverse social relations and each of those relations is autonomous.

Diversity brings differences and may lead to a conflict; however, a conflict is not always necessarily due to differences. Multiculturalism, either in local, national, or international level, generally has the equity and equality principles. Sparringa insisted that in order touphold these multiculturalism principles, revitalization, pro-existence, inclusion, and interaction are needed [2] The most evident consequence is that a social difference supports the cultural diversity through different perspectives on things potential to make social interaction among the members of a group, in which it may become difficult. A social conflict is a natural interaction process among the community. However, it becomes difficult when the social conflict among the community is no longer seen as a positive thing, but rather a destructive thing.

Within the interaction among the multi-ethnicity, the attitude that can minimize to utilize culture for negative purposes is required. Solidarity is developed based on the awareness that we do not choose our culture and we do not choose to live in a particular culture. Openness toward other cultures as long as those cultures are positive is needed and in accordance with multicultural principles. Besides, tolerance within cultural adaptation concept can become a wise and conflict-free solution.

Diversity and adaptation among ethnics, in general, happen in urban areas. The community often changes due to migration and urbanization that put together different cultures and ethnics, as well as different strata. The diversity phenomenon also happens in a school community at all levels of education. However, there are only several schools that have ethnic diversity and diverse social elements. These schools are especially schools that are favored by many people.

One of these schools is Madrasah Aliyah Negeri Insan Cendekia, Gorontalo (MAN ICG) — an Islamic boarding school at the level of high school; this school hasshown students and teachers' diversity as they came from all over Indonesia and live together under a coordinated institution. The atmosphere of diversity is strongly felt in this school. The students in this school come from various ethnic groups, social strata, and various regionsranging from Sumatra to Papua. 
The students live together in an area of interaction. Based on its diversity, this school has more diverse cultural community comparing to other communities in a group. The influence of multicultural life is strongly present in this community.

Various forms and attitudes of the student interaction in this school point out multiculturalism. Interestingly, this school is able to manage and control the diversity without any negative consequences. At the beginning of the school term, students usually form groups based on their original schools, ethnicities; yet, this sometimes leads to small conflicts and misunderstandings. However, as time goes and due to the management implemented by the school, which suited the students' diversity phenomenon, the students' socialization process has gone well, and misunderstandings and conflicts are slowly averted. Moreover, in this school the harmony and tolerance among different ethnicitiesare high. The social learning process of the students occurs as expected.

From their togetherness, student interaction happens as expected. As one of diverse social communities, sometimes misunderstanding occurs. This usually happens to students from different. However, in MAN ICG this is almost invisible and even does not happen at all. Further, considering this ethnic diversity, social strata, parents' education, and original school, this Islamic school shows the composition of a plural society. In its management, the school pays attention to that diversity by implementing norms and rules that control the life within the school. The norms and the regulation serve as a social control to manage the life in the school to influence individual behavior in theinteraction. In the daily interaction of a community, it is controlled by rules with a pattern to achieve a common goal. Waller describes that the function of the school is to influence the student's subconscious mind to be always consistent in practicing the criteria to interpret norms and regulation set by the school [3].

In general, this study is aimed at finding out the extent of multicultural ethos which is mobilized at the macro level to operate at the micro level, namely interpersonal relation at school. This would be described through the dynamics of a multicultural life by focusing on (1) the students management at MAN ICG, and (2) students' interaction patterns as the result of the management.

\section{METHOD}

Mix-approach method or quantitative and qualitative methods were used to describe the phenomenon on the student behavior. This approach was to collect the data and to understand the concept. The presence of the qualitative approach was to support and strengthen the lack of quantitative method and vice versa.

The student interaction pattern was studied through sociometry, and then analyzed using a qualitative approach. These were startedwith the mapping of social network among students which then was revealed through a distributed questionnaire. The questionnaire was then followed by an in-depth interview on the social process. The qualitative methodwas used to describe this phenomenon.

\section{RESULT}

\section{Interaction patterns of students in the class}

The number of students in grade $\mathrm{X}$ is 21 students, consisting of 9 males, and 12 females. The distributions of students are: one student is from Bangka Belitung, five students are from Jakarta and Tangerang, one student is from West Java, four students are from Central Java, two students are from East Java, one student is from South Sulawesi, one Student is from Central Sulawesi, four students are from Gorontalo, and two other students are from North Sulawesi. The parents' jobs also vary from farmers to employees of state-owned companies and from rural to urban areas.

a. Attraction and Mutual Attraction Interaction Pattern Below is the sociometry of grade $\mathrm{X}$, based on one of the questions in the questionnaire. "who is yourcurrent classmate that you want to keep as your classmate? Why? Where is she/he from?

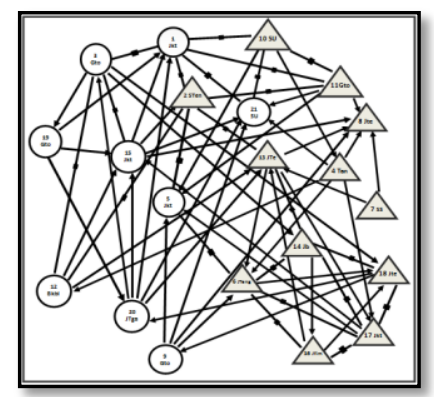

Figure 1. Attraction and mutual attraction interaction type.

$$
\begin{aligned}
& \text { notes: } \\
& -\quad \Delta \quad=\quad \text { = male } \\
& -
\end{aligned}
$$

From the figure above, it is clear that the interaction pattern is shifted among individuals or ethnics. The criterion for the selection here is keeping a friend whom they want to remainas their classmates. It is clear that the selection is distributed, which means that the selection is no longer based on their ethnicity. The sense of togetherness is very good. The reasons to select a friend are based on personal attitude and smartness.

It can be said that, from this interaction pattern, students in this class are multicultural; they come from different ethnics and social groups, and they form various interaction patterns regardless to their origins. Overall, they are able to maintain cross-ethnic friendships without selecting their friends according to their friend's origin. 
b. Rejection Mutual Rejection Interaction Pattern. The pattern below is a rejection and mutual rejection interaction pattern

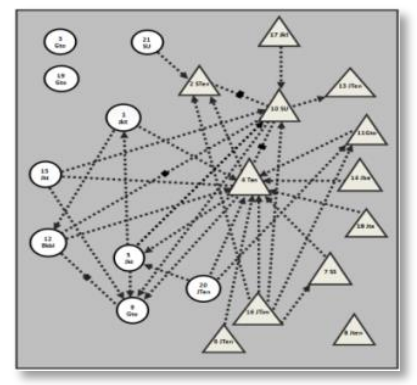

Figure 2. Rejection and mutual rejection interaction pattern in grade $\mathrm{X}$

Note:

$$
\begin{aligned}
-\quad \boldsymbol{O} & =\text { male } \\
-\quad \Delta & =\text { female } \\
& =\text { rejection } \\
& =\text { mutual rejection }
\end{aligned}
$$

From the sociometry above, it is clear that this class is a solid class, as from its 21 students; there are only two students that are less accepted. From the distribution of students' origin, and from the sociometry analysis, there is no grouping based on students' origin.

\section{Interaction Pattern in grade XI}

The total number of students in this class is 17 students, comprising ten females and seven males. From the distribution of social strata and the parents' jobs backgrounds, it shows that they come from various backgrounds; and for the positive question, "who is your current classmate that you would like to keep cooperating in all activities?", the responses on this question is described in the sociogram below:

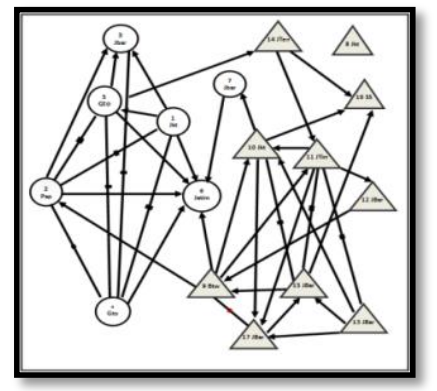

Figure 3. Attraction and mutual attraction interaction pattern in grade XI

a. Attraction and mutual attraction interaction pattern. The sociogram above shows that the selection is almost done with all students.

b. Rejection and mutual rejection interaction type pattern in grade XI. The interaction pattern of rejection and mutual rejection in this class happens only totwo male students..

This is interesting as in general there is not any rejection found among students. The researcher assumes that this is due to the adaptation time that has happened for more than a year in which the students have started to understand each other, accept each other's existence that is different from them selves', and are able to control their attitude as well as tolerate each other.

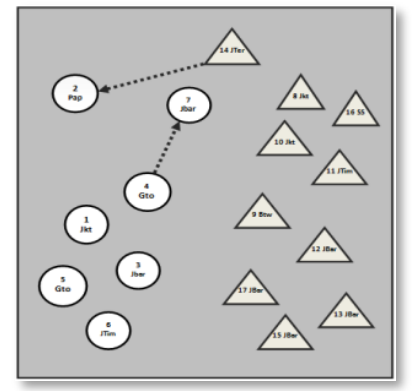

Figure 4. Rejection of interaction pattern in grade XI

If we compare this rejection interaction type with the rejection in grade X5, we would see a different outcome in which students of grade X5 clearly show the attitude of multiculturalism. Students in grade X5, who have known each other for only a semester, somehow still showa mutual rejection. However, there is not any specific hatred or things that may lead to a conflict. They only reject others for personal reasons, not due to ethnicity differences or other social differences.

\section{CONCLUSION}

According to Silvermen, interaction process in the school is not forced by moral imperatives; rather, it isan "assistant" for the students in the process of acquiring and improving the meaning of life that they live themselves [4]. Students interpret the normative meanings and expected actions according to the condition of their conscious mind. Based on this statement, several symbolic elements that tend to emerge in students were described as follow:

First, as choolis categorized as a means for students' social interaction, which is a social design to influence students' conscious mind to make them consistent in implementing the criteria of values insistedat school. Second, students interpret the values that are insisted into symbolic elements in their interactions. In absorbingthe symbolic meaning of the school environment, students internalize the objective meaning of their interaction from the school management and their environment through rules and regulationsbeing implemented in their social interaction where they assess, evaluate and control each other's actions and other individuals' behaviors.

As it is explained before, students who have gone through orientation and socialization time for six months in this school, have gained sufficient understanding and interpretation of their social environment. The establishment of interaction pattern that is distributed to all students with a very strong bond shows that students are able to understand the symbols that they accept from their interactional environment. Although the acceptance is strongly bounded, the acceptance for people outside the group is somehow difficult. 
Grade XI students have gone through longer socialization time as compared to grade $\mathrm{X}$. Their acceptance of symbolic meanings have been more deeplyrooted and interpreted through their social environment. The interaction pattern that is widely distributed to all students with a strong bond shows that students are able to make meaning to the symbols that they receive from their interaction environment. As time goes and the symbolic meaning of multiculturalism become more internalized; selection of friends showsa more extensive distribution although with a weaker bond.In addition, students have started to limit interaction with the opposite sex as they come to understand and internalizetheir religious teachings.

The interpretation of this is that the individual or group thatis able to internalizecertain symbolic meaning tend to dominate the objectification and internalization process of those symbolic meanings. Also, the individual or group that is able to absorbthe meaning of multiculturalism ideology tend to dominate the objectification process in their school environment. Almost all students are dominated by themselves-as "me", whichis determined by the school environment through the management pattern implemented by the school management.

Therefore, it can be interpreted that the individual or group of students in internalizing the meaning of multiculturalism ideology acceptance tend to dominate the objectification process and internalization of the meaning. Third, objectification process of the meaning of acceptance of multiculturalism occurs through students' interaction and school environment. In this sense, objectification of the meaning of multiculturalism ideology acceptance happens within the interaction among members of friend groups in the class and the school environment.

\section{REFERENCES}

[1] Salim, Agus. StratifikasiEtnik: Kajian Mikro Sosiologi Interaksi Jawa dan Cina. Yogyakarta: Tiara Wacana. 2006.
[2] Sparringga, Daniel. Multikulturalisme dari Pembiaran dan Ko-Eksistensi Menuju Proeksistensi dalam Diskriminasi di Sekililing Kita: Negara, Politik Diskriminasi dan Multikulturalisme. Yogyakarta: Institut Dian/Interfidei. 2003.

[3] Sherman, Lawrence W. Sociometry in the Classroom: How to do it. http://www.users.muohio.edu/shermalw/sociometry files/socio are.htmlx..

[4] Hamdan, Abdul Rahim. dkk. Fostering Intergroup Contacts among the Multiracial Students of Higher Education. UniversitiTeknologi Malaysia. 2009

[5] Rahardjo, M. Dawam. Merayakan Kemajemukan Kebebasandan Kebangsaan.Jakarta: Kencana 2010.

[6] Rifai, Muhammad. Sosiologi Pendidikan: Struktur dan Interaksi Sosial di dalam Institusi Pendidikan. Jogjakarta: Arruz Media. 2011.

[7] Salim, Agus. Pola Hubungan Antarsiswa dalam Masyarakat Multikultural. Studi Kasus terhadap Siswa SMP Maria Goretti di Kota Semarang. Disertasi tidak diterbitkan. Universitas Indonesia. Jakarta. 2005.

[8] Susan, Novri. Sosiologi Konflik dan Isu-isu Konflik Kontemporer. Jakarta: Kencana. 2009.

[9] Susetyo, D.P. Budi. Stereotip dan Relasi Antar Kelompok. Yagyakarta: Graha Ilmu. 2010

[10] Efendi, Anwar. Sekolah sebagai Tempat Persemaian Nilai Multikulturalisme.Jurnal Pemikiran Alternatif Pendidikan. Insania/Vol 13/No.1/Jan-Apr 2008. (halaman 55-66) 2008.

[11] Fuller, David P. An Investigation of Perspective Teachers on Dimensions of Diversity: Implications for Teacher Preparation Programs. Journal of Multicultural, Gender and Minority Studies, Volume 3, Issue 12009.

[12] Godina, Heriberto.Korean American Cultural Differences in Classroom Literacy Activities: Observations from an Ethnographic Case Study. Journal of Multicultural, Gender and Minority Studies, Volume 3, Issue 1. 2009. 